\title{
Breeding biofortified cowpea lines for semi-arid tropical areas by combining higher seed protein and mineral levels
}

\author{
C.A.F. Santos ${ }^{1}$ and L.S. Boiteux ${ }^{2}$ \\ ${ }^{1}$ Embrapa Semiárido, Petrolina, PE, Brasil \\ ${ }^{2}$ Embrapa Hortaliças, Brasília, DF, Brasil \\ Corresponding author: C.A.F. Santos \\ E-mail: carlos-fernandes.santos@embrapa.br
}

Genet. Mol. Res. 12 (4): 6782-6789 (2013)

Received April 17, 2013

Accepted September 5, 2013

Published December 16, 2013

DOI http://dx.doi.org/10.4238/2013.December.16.4

\begin{abstract}
One strategy to mitigate human malnutrition in semiarid areas is to increase the protein and mineral content of cowpea cultivars. Total seed protein, potassium, calcium, iron, zinc, and sodium contents were quantified in elite cowpea lines, with the aim to develop cultivars that had improved levels of these nutrients. Eightyseven $\mathrm{F}_{6}$ lines derived from 6 crosses were evaluated under rain-fed conditions in Petrolina, Brazil. Seed protein and mineral content were quantified by the micro-Kjeldhal method and in an atomic absorption spectrophotometer, respectively. Statistical analyses were estimated for all traits, including grain yield. Significant differences were observed for all characteristics. Seed protein content ranged from 22.5 to $34.1 \%$, potassium levels ranged from 20,200 to $27,000 \mathrm{ppm}$, and calcium levels ranged from 410 to $6260 \mathrm{ppm}$. Iron content ranged from 36.5 to $137 \mathrm{ppm}$, while zinc content ranged from 36 to $58 \mathrm{ppm}$ and sodium content ranged from 29.2 to $88 \mathrm{ppm}$. Simple correlation coefficient values indicated that selection for high protein and mineral content does not affect grain yield. These results demonstrate that it
\end{abstract}


is feasible to obtain new biofortified cowpea cultivars by combining higher levels of protein and essential minerals.

Key words: Vigna unguiculata; Semi-arid tropics; Human nutrition; Cultivars

\section{INTRODUCTION}

Protein-calorie malnutrition is a syndrome that affects millions of people in developing countries, mainly because of the high cost of obtaining protein of animal origin. Legumes, such as the cowpea [Vigna unguiculata (L.) Walp.], represent important alternatives for dietary protein supplementation, as long as they are associated with other calorie sources, such as cereals and cassava. The average protein content in cowpea seeds is around $25 \%$, with it containing adequate levels of all essential amino acids, except methionine, cystine, and cysteine (Iqbal et al., 2006).

An appropriate intake of microminerals is necessary for the human organism to meet its metabolic needs, and hence avoid a wide range of associated health problems (Welch and Graham, 2004). Deficiency in micronutrient nutrition (mainly iron and zinc) affects more than two million people worldwide, especially poor families in developing countries (Welch, 2002). Conventional intervention programs are dependent on the artificial supplementation of vitamins and minerals. Many of these programs have been proven to be unsustainable in a number of developing nations, because of their high operating costs (Welch and Graham, 2004; Mayer et al., 2008). Alternatively, biofortified agricultural products, such as cowpea varieties with higher mineral contents and agronomic adaptation to rural areas where the nutritional deficiencies are observed, might represent a powerful and sustainable intervention tool (Mayer et al., 2008).

Techniques to increase the total protein and mineral content of cowpea cultivars are considered as an important component of global intervention programs that are focused on alleviating human malnutrition, especially in semi-arid tropical areas. The cowpea is the most popular grain legume in Brazil, where it constitutes the main dietary source of protein and carbohydrate (Vasconcelos et al., 2010). In addition, the cowpea is a very important subsistence crop in semi-arid regions, particularly for people living in the Brazilian Northeast region, because of the natural ability of this species to withstand water stress conditions (Santos et al., 2012). Therefore, the development of improved cowpea cultivars that contain higher protein and mineral content in combination with good agronomic performance is expected to have important implications toward assuring food security in this geographic region.

Cowpea breeding lines with high protein and mineral content have been developed by various institutes, including the Instituto Nacional de Agricultura Tropical (IITA) (Singh, 2007). These results provide optimistic prospects toward achieving a substantial increase in the concentration of these nutritional components in elite lines from distinguished cowpea breeding programs, as long as the selection procedures are carried out correctly.

Despite the economic, social, and nutritional importance of the cowpea, the largescale development of new cultivars with higher mineral and protein content has only been conducted by a small number of institutes for the tropical semi-arid region (Frota et al., 2008). Hence, the main objective of the present study was to quantify the total seed protein, potas- 
sium, calcium, iron, zinc, and sodium in cowpea $\mathrm{F}_{6}$ breeding lines, with the aim to develop new biofortified cultivars that had improved levels of all these nutrients for cultivation under semi-arid tropical conditions.

\section{MATERIAL AND METHODS}

The lines assessed in the present study originated from a set of crosses involving 3 accessions introduced by the IITA ('IT97K-1042-3', 'IT99K-216-48-1', and 'IT97K-499') that had been previously identified as having high protein and mineral content (Singh, 2007), in addition to accessions adapted for cultivation in the Brazilian semi-arid tropical areas ('BRS Tapaihum', 'BRS Pujante', and 'Canapu').

Six crosses were carried out as follows: 'IT99K-216-48-1' x 'BRS Tapaihum', 'IT97K-1042-3' x 'BRS Tapaihum', 'IT97K-1042-3' x 'T16 Canapu', 'IT99K-216-48-1' x 'Canapu', IT97K-1042-3' x 'BRS Pujante', and 'IT97K-499' x 'T16 Canapu'. The advancement of generations from $F_{1}$ to $F_{5}$ was carried out under a sprinkler irrigation system at the Bebedouro Experimental Station (Petrolina, Pernambuco State, Brazil) by the single-pod descent method. Intense selection against virus susceptibility and for a short plant cycle (number of days to harvest) was carried out during the advances of the segregating generations.

The $\mathrm{F}_{6}$ lines were field-assessed in a rain-fed environment at the Caatinga Experimental Station (Petrolina, Pernambuco State, Brazil) in 2010, using randomized blocks with 2 replications. The plant spacing was $1.0 \mathrm{~m} \times 0.1 \mathrm{~m}$, and each experimental unit contained 1 line of $2 \mathrm{~m}$ in length. The plants were sprayed twice with insecticides during the growing season to control aphids and prevent weevil infestation.

The seed total protein content was quantified by the micro-Kjeldhal method (AOAC, 1995). Five milliliters of digestion solution was added to $100 \mathrm{mg}$ dry cowpea seeds. The digestion took place in a digester block with a gradual increase in temperature to $370^{\circ} \mathrm{C}$ to completely fix the protein nitrogen in ammonia, in the form of ammonium sulfate. The nitrogen was then distilled and removed in the form of ammonia in $2 \%$ boric acid, forming borate ions that were titered with standardized sulfuric acid to quantify the protein nitrogen, and for later conversion to total protein content. The results were expressed in percentage protein, with an adjustment to dry weight. The total proteins were analyzed in the Animal Nutrition Laboratory at Embrapa Semiárido (Brazilian Agricultural Research Corporation, Tropical Semiarid Center). Total protein quantification analyses using the micro-Kjeldhal method were carried out following the previously reported methods (Nielsen et al., 1993; Giami, 2005; Frota et al., 2008).

The mineral content [including potassium $(\mathrm{K})$, calcium $(\mathrm{Ca})$, iron $(\mathrm{Fe})$, zinc $(\mathrm{Zn})$, and sodium (Na)] was quantified according to the AOAC (1995) methodology. Five milliliters of nitric acid and $1 \mathrm{~mL}$ perchloric acid were added to each $500 \mathrm{mg}$ cowpea sample for acid digestion, which was carried out in a block digester. Extract A was prepared to determine Fe, Zn, and Na. After chilling the digester tubes, $49 \mathrm{~mL}$ distilled and deionized water was added. The samples were then read in a Varian atomic absorption spectrophotometer. Extract B was prepared to determine $\mathrm{K}$ and $\mathrm{Ca}$. One milliliter of extract $\mathrm{A}$ was transferred to a $50-\mathrm{mL}$ beaker, identified by the sample protocol number, and $49 \mathrm{~mL}$ lanthanum oxide was added. Then, the extract $\mathrm{B}$ samples were read in a Varian atomic absorption spectrophotometer. The results are reported in part per million (ppm) or $\mathrm{mg} / \mathrm{kg}$ grain (dry weight). Analyses to quantify the minerals in the grains employed here were essentially similar to those reported by Frota et al. (2008) and Belane and Dakora (2011). 
Two analyses were carried out for each sample from each experimental plot. These analyses were replicated when the results between the 2 replications of each treatment were different, either for total proteins or minerals. The protein and mineral content results were subjected to analysis of variance and simple correlations using the SAS system (SAS, 1989). Cowpea $\mathrm{F}_{6}$ lines that presented equivalent and/or superior grain yield in comparison to standard cultivars and total protein content greater than $28 \%$ were selected for future assessment under various environment conditions, with the aim to identify more suitable accessions for potential release as new commercial cultivars.

\section{RESULTS AND DISCUSSION}

Eighty-seven of the 107 lines cultivated in the field produced enough seeds for protein and mineral quantification. A drought period (without rain) of 20 days occurred during the growing season, which might have influenced both the survival rate and agronomic performance of the lines evaluated. The cross 'IT97K-1042-3' x 'BRS Pujante' produced the smallest number of lines evaluated, indicating that the progeny of this cross might not have tolerance mechanisms to withstand semi-arid conditions, particularly the drought stress observed during the field assay. The highest number of lines assessed was obtained from the crosses 'IT99K216-48-1' x 'BRS Tapaihum' and 'IT97K1042-3' x 'BRS Tapaihum' (Table 1), with the lines of both progenies exhibiting a short plant cycle, around sixty days after seed sowing.

Table 1. Means, value ranges, treatment square means, and coefficient of variation for grain yield, seed protein, and mineral levels quantified in $87 \mathrm{~F}_{6}$ cowpea lines derived from 6 different crosses, and assessed under rain-fed conditions at Petrolina, PE, Brazil, in 2010.

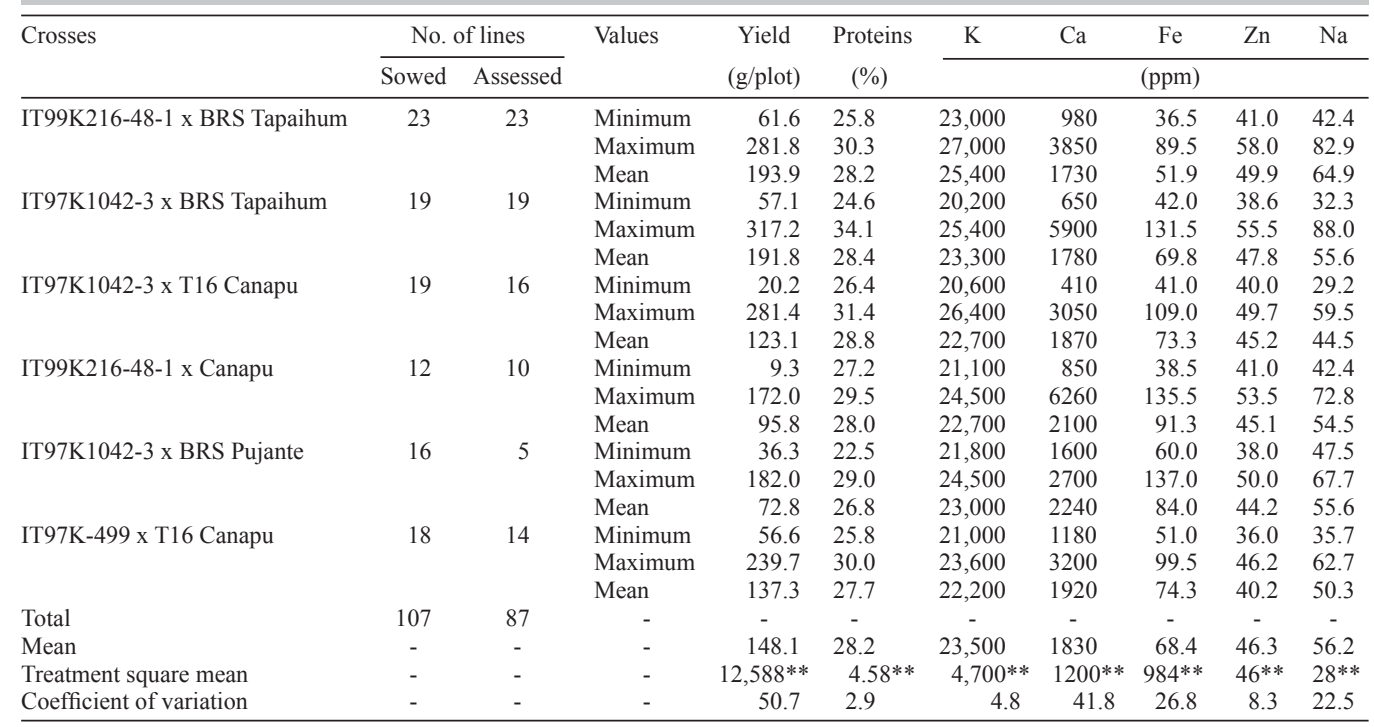

**Significant at $5 \%$ probability by the $\mathrm{F}$ test.

All the variables analyzed were significant $(\mathrm{P}<0.05$ or 0.01$)$, with the coefficient of variation ranging from 2.9 to $50.7 \%$, indicating high variability for all the traits (except for grain yield and calcium content). These results also indicate adequate experimental conditions for the 
selection of superior lines for these set of traits (Table 1). The highest total protein value (34.1\%) was observed in 1 line derived from the cross 'IT97K1042-3' x 'BRS Tapaihum' (Table 1), indicating that a significant increase in the total protein content is possible in cowpea lines adapted to semi-arid cropping conditions. Maximum total protein values, either equal to or greater than $30 \%$, were observed in lines derived from all of the other crosses. These values were higher compared to the mean value of $25 \%$ previously reported for other $V$. unguiculata accessions (Iqbal et al., 2006). Nielsen et al. (1993) reported total protein values ranging from 22.9 to $32.5 \%$ after the analysis of 100 high seed protein-accumulating elite lines from the IITA program.

The highest potassium value $(27,000 \mathrm{ppm})$ was observed in 1 line derived from the cross 'IT99K216-48-1' x 'BRS Tapaihum'. The maximum average values observed in lines derived from distinct crosses (Table 1) were greater compared to those reported by Singh (2007), who recorded 16,150 ppm during the analysis of 50 cowpea cultivars in Australia. Frota et al. (2008) reported a potassium concentration of 14,300 ppm in the cowpea cultivar 'BRS Milênio', which is an inferior value compared to those observed in some lines evaluated in the present study.

The highest value for calcium content $(6260 \mathrm{ppm})$ was observed in 1 line derived from the cross 'IT99K216-48-1' x 'Canapu', while the overall values observed for the lines from all other crosses were either equivalent to or above those reported by Singh (2007), who recorded a calcium content of $1300 \mathrm{ppm}$ during the analysis of 50 cowpea cultivars in Australia. Iqbal et al. (2006) reported $1760 \mathrm{ppm}$ calcium content in a cowpea accession in Peshawar, Pakistan, while Frota et al. (2008) reported 1400 ppm calcium content in the cowpea cultivar 'BRS Milênio'. Belane and Dakora (2011) reported a calcium content range of 1000 to $1456 \mathrm{ppm}$ in the grains of 27 cowpea cultivars assessed in Ghana. The values obtained in all these studies were lower compared to the values observed in some of the breeding lines evaluated in the present study.

The highest iron value (137 ppm) was observed in the 'IT97K1042-3' x 'BRS Pujante' cross, while the maximum values observed in individual lines from the other crosses were higher compared to the maximum value reported by Singh (2007), who obtained $79.1 \mathrm{ppm}$ in Australia. Iqbal et al. (2006) reported 26 ppm iron, while Frota et al. (2008) reported 68 and 77.4 ppm iron content in the cowpea cultivars 'BRS Milênio' and 'BRS Xiquexique', respectively. Belane and Dakora (2011) reported a range of 60 to $137 \mathrm{ppm}$ iron in the grains of 27 cowpea cultivars assessed in Ghana, with this variation being quite similar to that observed in the present study.

The greatest zinc level $(58 \mathrm{ppm})$ was observed in 1 line derived from the cross 'IT99K216-48-1' x 'BRS Tapaihum', while the maximum values observed for all other crosses were close to the maximum (48 ppm) reported by Singh (2007). Iqbal et al. (2006) reported a maximum zinc content of $51 \mathrm{ppm}$, while Frota et al. (2008) reported 41 and $53.56 \mathrm{ppm}$ zinc content in the cowpea cultivars 'BRS Milênio' and 'BRS Xiquexique', respectively. Belane and Dakora (2011) reported a range from 44 to $61 \mathrm{ppm}$ zinc in the grains of 27 cowpea cultivars, with the maximum value being very similar to that observed in the present study.

The highest sodium content ( $88 \mathrm{ppm}$ ) was observed in 1 line from the 'IT971042-3' x 'BRS Tapaihum' cross; however this value was lower compared to the 204 ppm previously reported for the cultivar 'BRS Milênio' (Frota et al., 2008). Singh (2007) reported a range in sodium content from 24.6 to $255 \mathrm{ppm}$ in a collection of the $V$. unguiculata accessions.

Basic correlation analysis for grain yield, total protein, and mineral content in $\mathrm{F}_{6}$ cowpea lines produced values ranging from -0.47 to 0.56 (Table 2). Total protein content had no statistically significant impact on either grain yield or on the concentration of all 5 minerals analyzed (Table 2). However, grain yield was negatively correlated with seed potassium and calcium levels, but 
positively correlated with iron and sodium levels. The zinc and iron levels in the seeds were not correlated, but they were positively and negatively correlated with potassium levels, respectively.

Table 2. Simple correlation for grain yield, total protein, and minerals in $87 \mathrm{~F}_{6}$ lines resulting from 6 crosses among different cowpea cultivars, and assessed under rain-fed conditions at Petrolina, PE, Brazil, in 2010.

\begin{tabular}{|c|c|c|c|c|c|c|}
\hline & Grain yield & Potassium & Calcium & Iron & Zinc & Sodium \\
\hline Total protein & -0.19 & -0.12 & 0.06 & 0.19 & 0.19 & -0.18 \\
\hline Grain yield & & $-0.38^{* *}$ & $-0.25^{*}$ & $0.46^{* *}$ & 0.01 & $0.41 * *$ \\
\hline Potassium & & & 0.01 & $-0.47 * *$ & $0.49^{* *}$ & $0.56^{* *}$ \\
\hline Calcium & & & & 0.18 & -0.02 & -0.03 \\
\hline Iron & & & & & -0.02 & $-0.45^{* *}$ \\
\hline Zinc & & & & & & $0.25 *$ \\
\hline
\end{tabular}

*Significant at $1 \%$ probability and $* *$ significant at $5 \%$ probability by the $t$-test.

Thirty-six cowpea $\mathrm{F}_{6}$ lines were selected for future multi-location assessments, with the aim to identify more suitable accessions for potential release as commercial cultivars. These lines displayed equivalent and/or superior grain yield compared to standard cultivars and total protein content greater than $28 \%$ (Table 3 ).

Table 3. Grain yield $(\mathrm{kg} / \mathrm{ha})$, protein content, mineral content $(\mathrm{K}, \mathrm{Ca}, \mathrm{Fe}, \mathrm{Zn}$, and $\mathrm{Na})$, and plant type of $\mathrm{F}_{6}$ cowpea lines selected for future assessments in distinct environments in the semi-arid tropical region of Brazil.

\begin{tabular}{|c|c|c|c|c|c|c|c|c|}
\hline Line & Cross & Protein $(\%)$ & Yield (kg/ha) & $\mathrm{K}(\mathrm{ppm})$ & $\mathrm{Ca}(\mathrm{ppm})$ & $\mathrm{Fe}(\mathrm{ppm})$ & $\mathrm{Zn}(\mathrm{ppm})$ & $\mathrm{Na}(\mathrm{ppm})$ \\
\hline $\mathrm{C} 2 \mathrm{R}$ & IT97K1042 x Tapaihum & 34.1 & 635 & 22,115 & 1775 & 88.5 & 50.0 & 42.4 \\
\hline C3S & IT97K1042 x T16 Canapu & 31.3 & 504 & 23,945 & 1945 & 63.6 & 45.6 & 47.7 \\
\hline $\mathrm{C} 2 \mathrm{M}$ & IT97K1042 x Tapaihum & 31.2 & 861 & 22,650 & 1625 & 128.5 & 54.5 & 47.5 \\
\hline $\mathrm{C} 1 \mathrm{~N}$ & IT99K216 x Tapaihum & 30.3 & 845 & 25,800 & 1600 & 48.0 & 50.0 & 62.6 \\
\hline $\mathrm{C} 3 \mathrm{M}$ & IT97K1042 x T16 Canapu & 30.2 & 733 & 22,455 & 2925 & 83.5 & 45.0 & 37.3 \\
\hline C1R & IT99K216 x Tapaihum & 30.1 & 708 & 25,000 & 3850 & 53.5 & 47.5 & 52.5 \\
\hline C3Q & IT97K1042 x T16 Canapu & 30.1 & 250 & 19,885 & 1295 & 78.6 & 49.6 & 27.4 \\
\hline $\mathrm{C} 3 \mathrm{O}$ & IT97K1042 x T16 Canapu & 30.0 & 1345 & 23,475 & 3050 & 109.0 & 40.0 & 37.3 \\
\hline $\mathrm{C} 2 \mathrm{I}$ & IT97K1042 x Tapaihum & 29.9 & 420 & 22,650 & 2300 & 131.5 & 55.0 & 32.3 \\
\hline $\mathrm{C} 1 \mathrm{G}$ & IT99K216 x Tapaihum & 29.6 & 1258 & 25,805 & 1575 & 50.5 & 50.0 & 82.9 \\
\hline $\mathrm{C} 1 \mathrm{~S}$ & IT99K216 x Tapaihum & 29.6 & 745 & 24,595 & 1375 & 46.0 & 51.0 & 57.6 \\
\hline C3B & IT97K1042 x T16 Canapu & 29.6 & 650 & 22,460 & 1875 & 68.5 & 44.5 & 52.5 \\
\hline C6P & IT97K499 x T16 Canapu & 29.6 & 457 & 23,135 & 1725 & 74.0 & 46.0 & 62.6 \\
\hline $\mathrm{C} 1 \mathrm{M}$ & IT99K216 x Tapaihum & 29.4 & 1061 & 25,000 & 1375 & 42.0 & 50.0 & 62.6 \\
\hline $\mathrm{C} 2 \mathrm{~J}$ & IT97K1042 x Tapaihum & 29.4 & 285 & 22,585 & 1425 & 96.5 & 53.0 & 32.3 \\
\hline $\mathrm{C} 3 \mathrm{~F}$ & IT97K1042 x T16 Canapu & 29.4 & 175 & 21,445 & 1000 & 68.0 & 47.0 & 37.3 \\
\hline $\mathrm{C} 3 \mathrm{~L}$ & IT97K1042 x T16 Canapu & 29.3 & 706 & 21,780 & 1075 & 88.5 & 48.0 & 47.5 \\
\hline $\mathrm{C} 2 \mathrm{C}$ & IT97K1042 x Tapaihum & 29.2 & 1412 & 23,395 & 1325 & 55.0 & 43.5 & 62.6 \\
\hline $\mathrm{C} 1 \mathrm{~J}$ & IT99K216 x Tapaihum & 29.0 & 1092 & 25,800 & 1900 & 41.5 & 43.0 & 72.7 \\
\hline $\mathrm{C} 1 \mathrm{~F}$ & IT99K216 x Tapaihum & 28.9 & 1184 & 27,010 & 1300 & 48.5 & 54.5 & 72.7 \\
\hline $\mathrm{C} 1 \mathrm{~T}$ & IT99K216 x Tapaihum & 28.8 & 836 & 25,805 & 1800 & 48.0 & 52.0 & 67.7 \\
\hline $\mathrm{C} 2 \mathrm{O}$ & IT97K1042 x Tapaihum & 28.8 & 1260 & 22,990 & 1425 & 49.0 & 46.5 & 62.6 \\
\hline $\mathrm{C} 2 \mathrm{~S}$ & IT97K1042 x Tapaihum & 28.8 & 506 & 25,135 & 5845 & - & - & - \\
\hline $\mathrm{C} 3 \mathrm{R}$ & IT97K1042 x T16 Canapu & 28.8 & 588 & 24,625 & 2195 & 90.6 & 48.6 & 57.8 \\
\hline $\mathrm{C} 2 \mathrm{~B}$ & IT97K1042 x Tapaihum & 28.7 & 1152 & 23,390 & 1225 & 52.0 & 42.0 & 62.6 \\
\hline $\mathrm{C} 4 \mathrm{G}$ & IT99K216 x Canapu & 28.7 & 680 & 23,135 & 1425 & 135.5 & 45.0 & 42.4 \\
\hline $\mathrm{C} 2 \mathrm{~A}$ & IT97K1042 x Tapaihum & 28.6 & 1219 & 22,990 & 3350 & 59.0 & 49.0 & 87.9 \\
\hline C6A & IT97K499 x T16 Canapu & 28.6 & 550 & 23,945 & 2395 & 57.6 & 43.6 & 47.7 \\
\hline $\mathrm{C} 2 \mathrm{Q}$ & IT97K1042 x Tapaihum & 28.5 & 1062 & 24,600 & 925 & 42.0 & 44.5 & 62.6 \\
\hline $\mathrm{C} 2 \mathrm{~T}$ & IT97K1042 x Tapaihum & 28.5 & 449 & 19,885 & 745 & 80.6 & 38.6 & 37.5 \\
\hline $\mathrm{C} 3 \mathrm{P}$ & IT97K1042 x T16 Canapu & 28.5 & 589 & 20,555 & 1845 & 72.6 & 43.6 & 37.5 \\
\hline $\mathrm{C} 1 \mathrm{O}$ & IT99K216 x Tapaihum & 28.4 & 1299 & 25,000 & 1825 & 45.5 & 51.0 & 47.5 \\
\hline C6D & IT97K499 x T16 Canapu & 28.3 & 892 & 22,185 & 1650 & 99.5 & 36.5 & 52.5 \\
\hline C1I & IT99K216 x Tapaihum & 28.2 & 963 & 26,205 & 1225 & 47.0 & 50.0 & 77.8 \\
\hline $\mathrm{C} 1 \mathrm{~V}$ & IT99K216 x Tapaihum & 28.2 & 674 & 24,195 & 1475 & 64.5 & 52.5 & 72.7 \\
\hline $\mathrm{C} 4 \mathrm{I}$ & IT99K216 x Canapu & 28.2 & 848 & 22,800 & 1625 & 65.5 & 41.5 & 57.6 \\
\hline
\end{tabular}


The basic correlation analyses indicated that the increase in the total protein content did not have a negative impact on grain production or the concentration of any of the 5 minerals (Table 2). Grain yield might be negatively impacted by an increase in potassium and calcium content, but positively impacted by an increase in iron and sodium content in cowpeas. Correlations between potassium $\mathrm{x}$ iron and iron $\mathrm{x}$ sodium displayed significantly negative values, indicating that it will be difficult to develop cowpea lines in which all 3 minerals simultaneously increase. However, it is important to note that zinc and iron levels in the seeds were not correlated. These minerals are more important breeding targets in terms of human nutrition, particularly because of their natural low levels in many staple crops, such as cereals and cassava (Mayer et al., 2008).

The daily protein requirement for adults, including pregnant or lactating women, is $0.66 \mathrm{~g} / \mathrm{kg}$ or $105 \mathrm{mg}$ nitrogen $/ \mathrm{kg}$ body weight (WHO, 2002). The lines selected for multi-location assessments (Table 3 ) had protein values of over $28 \%$. Therefore, the intake of around 100 $\mathrm{g}$ seeds derived from these lines would contribute to fulfill the daily protein ingestion requirement. In comparison, goat meat, which is considered a high-quality protein source, has mean values of $22 \%$ protein (Johnson et al., 1995), which highlights the importance of developing cowpea cultivars that have high protein content.

Santos et al. (2012) reported transgressive $\mathrm{F}_{2}$ lines that had protein content with values reaching up to $34 \%$. In the present study, we identified 1 line (named ' $\mathrm{C} 2 \mathrm{R}$ ') that had protein levels of $34.1 \%$, which corresponded to the highest cowpea seed protein level reported in the literature to date. In addition, new segregating populations may be generated with the aim to simultaneously increase yield, protein content, and zinc and iron levels using crosses from selected lines, such as ' $\mathrm{C} 2 \mathrm{R}$ ', ' $\mathrm{C} 3 \mathrm{O}$ ', and ' $\mathrm{C} 2 \mathrm{C}$ ' (Table 3). Therefore, it is reasonable to assume that the average protein content in the cowpea should be increased to close to $35 \%$, which would improve its nutritional quality for human populations living in semi-arid regions, in addition to serving as a raw material option for the food processing industry.

The daily requirement of dietary calcium during childhood ranges from 350 to 800 $\mathrm{mg}$ (WHO, 2002), while the daily ingestion requirement of potassium ranges from 1000 to $1600 \mathrm{mg}$ for children 1 to 9 years old (UMMC, 2011). Despite the limitations indicated in the basic correlation analysis for the concomitant increase of grain yield with potassium and calcium (Table 2), the daily intake of $100 \mathrm{~g}$ grains of a sub-set of the selected lines (considering only the concentration of these minerals in the grains) could meet the daily requirements for potassium intake and around 30 to $50 \%$ of the daily calcium intake requirements. Similarly, the intake of $50 \mathrm{~g}$ of some of the selected lines would be sufficient to meet the average dietary human requirement per day of iron and zinc, which ranges from 8 to $27 \mathrm{mg}$ and from 2 to 13 $\mathrm{mg}$, respectively (UMMC, 2011). The bioavailability of iron and zinc increased in rats fed with bean and rice accessions containing higher concentrations of these minerals (Welch et al., 2000). Welch (2002) also observed that most of the geographic regions where populations present severe micronutrient deficiency co-localize in areas that have a natural occurrence of micronutrient-poor soils. It was also observed that the increase in levels of micronutrients in the grains also favors the agronomic performance of biofortified genotypes in soils that are naturally deficient in these minerals (Welch, 2002). In addition, plants with lower concentrations of phytate improved the bioavailability of zinc and iron (Welch et al., 2000). Therefore, selection for lower levels of natural compounds that reduce the bioavailability of micronutrients in the human diet should also be a novel target for future breeding research aiming to develop biofortified cowpea cultivars. 
Cowpea is a very important legume crop in semi-arid regions because of its ability to withstand water stress, in addition to being a strategic source of high-quality protein and minerals that is far less expensive compared to that of animal origin or compared to plant products imported into the Brazilian semi-arid region (Santos et al., 2012). In this context, the selection of semi-arid-adapted cowpea lines that have high protein and mineral content associated with good agronomic performance is expected to be an important contribution to the economic development of the region. In the present study, elite lines displaying superior grain yield under water shortage conditions and with higher total protein content were selected for future assessments under several environmental conditions within the Brazilian tropical semi-arid area to identify the most suitable lines for potential release as new cowpea cultivars adapted to the agro-ecological region.

\section{ACKNOWLEDGMENTS}

The authors thank Conselho Nacional de Desenvolvimento Científico e Tecnológico (CNPq) for financial support.

\section{REFERENCES}

Association of Official Analytical Chemists (AOAC) (1995). Official Method 920.87 - Protein (total) in Flour, Final Action. In: Official Methods of Analysis of the Association of Official Analytical Chemists (Cunniff P, ed.). AOAC, Arlington, 12-13.

Belane AK and Dakora FD (2011). Levels of nutritionally-important trace elements and macronutrients in edible leaves and grain of 27 nodulated cowpea (Vigna unguiculata L. Walp.) genotypes grown in the Upper West region of Ghana. Food Chem. 125: 99-105.

Frota KMG, Soares RAM and Arêas JAG (2008). Chemical composition of cowpea (Vigna unguiculata L. Walp), cultivar BRS-Milênio. Ciênc. Tecnol. Aliment. 28: 470-476.

Giami SY (2005). Compositional and nutritional properties of selected newly developed lines of cowpea (Vigna unguiculata L. Walp). J. Food Compos. Anal. 18: 665-673.

Iqbal A, Khalil IA, Ateeq N and Khan MS (2006). Nutritional quality of important food legumes. Food Chem. 97: 331-335.

Johnson DD, Eastridge JS, Neubauer DR and McGowan CH (1995). Effect of sex class on nutrient content of meat from young goat. J. Anim. Sci. 73: 296-301.

Mayer JE, Pfeiffer WH and Beyer P (2008). Biofortified crops to alleviate micronutrient malnutrition. Curr. Opin. Plant Biol. 11: 166-170.

Nielsen SS, Brandt WE and Singh BB (1993). Genetic variability for nutritional composition and cooking time of improved cowpea lines. Crop Sci. 33: 469-472.

Santos CAF, Costa DCC da, Silva WR da S and Boiteux LS (2012). Genetic analysis of total seed protein content in two cowpea crosses. Crop Sci. 52: 2501-2506.

SAS (1989). SAS/STAT User's Guide. Version 6, 4th edn. SAS Institute Inc., Cary.

Singh BB (2007). Recent progress in cowpea genetics and breeding. Acta Hortic. 752: 69-75.

University of Maryland Medical Center (UMMC) (2011). Potassium. [http://www.umm.edu/altmed/articles/ potassium-000320.htm]. Accessed August 15, 2011.

Vasconcelos IM, Maia FMM, Farias DF and Campello CC (2010). Protein fractions, amino acid composition and antinutritional constituents of high-yielding cowpea cultivars. J. Food Compos. Anal. 23: 54-60.

Welch RM (2002). Breeding strategies for biofortified staple plant foods to reduce micronutrient malnutrition globally. $J$. Nutr. 132: 495S-499S.

Welch RM and Graham RD (2004). Breeding for micronutrients in staple food crops from a human nutrition perspective. J. Exp. Bot. 55: 353-364.

Welch RM, House AW, Beebe S, Senadhira D, et al. (2000). Testing iron and zinc bioavailability in genetically enriched beans (Phaseolus vulgaris L.) and rice (Oryza sativa L.) in rat model. Food Nutr. Bull. 21: 428-433.

World Health Organization (WHO) (2002). Protein and Amino Acid Requirements in Human Nutrition: Report of a Joint FAO/WHO/UNU Expert Consultation. WHO Technical Report Series, Geneva. 